\title{
Jus Post Bellum Viewed from the Colombian Transition
}

This chapter aims to connect the previous two. Chapter 1 explored the concept of jus post bellum as the analytical framework for framing the role of international law governing transition from armed conflict to peace. Chapter 2 examined the role played by international law in different areas of the Colombian transition, identifying the relevant legal framework and how it has shaped several transitional instruments in the country. This third chapter assesses the concept of jus post bellum from the perspective of the Colombian experience to identify how theory is reflected in practice and how the Colombian practice offers new insights on the content and the scope of jus post bellum as the normative framework for transitioning from armed conflict to sustainable peace.

The main argument of this chapter is that the way in which international law has molded transition in Colombia reflects most of the theoretical elaborations on jus post bellum. As such, considering that no previous work has analyzed jus post bellum comprehensively through a case study, this chapter suggests empirical insights to delineate the definition, the content, the formation, the actors, and the functions of jus post bellum, contrasting the theoretical basis introduced in Chapter 1 to the Colombian case presented in Chapter 2.

This chapter thus refers back to the approaches to defining jus post bellum discussed in the first chapter to address whether they work in practice and what definition could be proposed in light of the experience in Colombia. Then, by using concrete examples in the Colombian process, the chapter analyses how jus post bellum is permanently built through practice, because of the dual process of application and creation of law occurring in negotiations and transitions to peace. The chapter also readdresses the discussion on principles of jus post bellum presented in the first chapter to explain why they constitute the substantive content of the concept and to suggest a series of principles that can be identified in the Colombian case. The chapter thus analyzes how the variety of actors involved in the normative internationalization of the Colombian transition shows the broad spectrum of potential actors of jus post bellum, which are not limited to the parties in negotiation. Finally, the chapter assesses the functions played by international law in the Colombian transition, suggesting the potential functions that jus post bellum can serve as 
the normative framework guiding successful transition from armed conflict to sustainable peace.

\section{A Definition of Jus Post Bellum from the Colombian Experience}

Assessing the elements from theory and practice discussed in the previous chapters, it can be observed that, at present, jus post bellum is still a concept of scholarly use. It is not yet used in the official UN and state language and does not have a recognized normative standing on its own. At the time of writing only one mention to the concept was found in a UN document, consisting in the 2016 ILC's Special Rapporteur Marie Jacobsson's Third Report on the Protection of the Environment in Relation to Armed Conflicts. ${ }^{1}$ However, the Special Rapporteur mentioned the concept to mean that she was not going to address the "legal-political discussion" on jus post bellum in her report, because, in her opinion, "this concept is wider than positive law and has a clear connection to just war theories."2 Even though her reasons are inaccurate, since transition to peace necessarily involves more than positive law and the concept of jus post bellum already has a legal development beyond its original conception within the just war theory, ${ }^{3}$ the Special Rapporteur's statement not to address the concept in her report shows the challenges from bringing the concept into the official practice.

In that sense, it is clear that even if the parties in a peace process are aware of existing legal considerations shaping their negotiation and the resulting agreement, they do not identify these elements as belonging to or constituting a specific legal framework for transition. Nevertheless, though the concept of jus post bellum is not yet officially used in practice, it offers an effective framework for designating the legal norms, discourses, and practices that apply to the transition from armed conflict to sustainable peace.

The different definitions discussed in Chapter 1 offer useful elements to build an integrative approach. As analyzed in that chapter, existing definitions can be grouped under three approaches to jus post bellum: 1) as a new legal regime; 2 ) as an ordering system; and 3 ) as an interpretative framework. ${ }^{4}$

1 Marie Jacobsson Special Rapporteur, 'Third Report on the Protection of the Environment in Relation to Armed Conflicts' (Geneva: International Law Commission, 2016).

2 Jacobsson, para. 10.

3 See Introduction, Sections 3 and 8.

4 Stahn, 'Jus Post Bellum and the Justice of Peace: Some Preliminary Reflections.' 
Regarding jus post bellum as a new legal regime, in addition to the criticism exposed in Chapter 1, practice in Colombia confirms that such a formal regime would not be possible nor consistent with the inner flexibility of peacemaking. The negotiators and other actors involved in the process took norms from different international legal instruments and branches of law, based on the matters in negotiation. Those matters could be significantly different in other transitional contexts, and the relevant actors could even use or apply the same norms in a different way. Even in Colombia, the application of ICL standards to sanctions for people responsible for serious armed conflict-related crimes was different in the 2005 Justice and Peace Law compared to the 2016 Peace Agreement. As such, jus post bellum must be open, flexible, and able to combine different legal and political considerations according to the needs of the context.

However, the two other approaches to defining jus post bellum can be supported in practice. Jus post bellum can work as a framework ordering legal norms, discourses, and practices defining the normative bargaining zone in which parties can move to create their own transitional formulas. At the same time, such a framework can offer interpretative elements on how those norms should be understood and applied to the specific context. Two examples illustrate this argument in Colombia. One example is the way in which the system of criminal justice negotiated by the parties was influenced by IHL and ICL norms regarding amnesties and prosecution for international crimes, by the ICC Prosecutor's discourses on how to ensure sanctions compatible with ICL, and by comparative practices on transitional justice. ${ }^{5} \mathrm{~A}$ second example can be found in the way in which international standards on women's participation in peace processes set by UNSC Resolution 1325 came together with different discourses on inclusiveness, leading to a broad approach to participation involving not only women but also LGBTI and ethnic groups. ${ }^{6}$ In both cases, one can see that legal norms, discourses, ${ }^{7}$ and comparative practices framed a zone of negotiation showing the parties' limits and possibilities in coordinating, interpreting, and applying the international legal framework relevant to their transition to peace.

Considering said ideas, a definition of jus post bellum from practice is based on four elements. The first is the possible content of jus post bellum. Here, a

5 See Chapter 2, Section 3.

6 See Chapter 2, Section 5 .

7 Regarding the value of legal discourses, Kastner argues: "that discourse is not only illustrative but constitutive of the normative framework." Kastner, Legal Normativity in the Resolution of Internal Armed Conflict, 32. 
set of principles seems more appropriate than a formal legal regime. In the Colombian transition, legal norms from different branches of international law defined matters of the peace negotiation and of the previous transitional instruments. However, those norms were not applied in a linear process; rather, the parties took elements from legal discourses, comparative experiences, and the practical needs of the context to define a way to interpret and apply legal norms in a manner consistent with the pursuit of peace. Thus, the parties were guided by principles defining a framework on the legal and the political considerations to be addressed. ${ }^{8}$

The second element is the object of jus post bellum, which, as discussed in Chapter 1, consists in contributing to establish a sustainable peace. ${ }^{9}$ This book has argued that sustainable peace requires at least two conditions: first, addressing the root causes of armed conflict, which is the only way to promote reconciliation and prevent the recurrence of violence; and second, observing adherence to relevant standards of international law, which are essential to ensure the rule of law, respect for human rights, democratic governance, and international legitimacy. In the Colombian case, transition has entailed not only ending armed confrontation but also building peace, ${ }^{10}$ seeking to remove the causes of the conflict, meeting victim's rights, and encouraging reconciliation under an international legal framework.

The third element is a functional rather than a temporal approach.Jus post bellum is not a regime with starting and ending benchmarks. It is a framework providing guidance during any phase when efforts are put in place to end armed conflict and to establish sustainable peace. ${ }^{11}$ As seen in Chapter 2 , Colombia is an example on the use of normative principles of criminal justice ${ }^{12}$ and reparations ${ }^{13}$ even before having a peace process. Moreover, despite a comprehensive peace agreement in the country, armed conflict is still ongoing with another

8 Easterday, 'Peace Agreements as a Framework for Jus Post Bellum,' 386.

9 See Chapter 1, Section 4.

10 It can be seen even since the name of the agreement, called Final Agreement to End the Armed Conflict and Build a Stable and Lasting Peace. Government of Colombia and FARC, 'Final Agreement to End the Armed Conflict and Build a Stable and Lasting Peace.' At this regard, the book follows Larry May's approach, who, as noted in Chapter 1, Section 3 , suggests that "jus post bellum refers to any principles that govern the mopping up efforts, namely the efforts at the end and after the end of war that lead into a position of peace." May, After War Ends, 3.

12 Congreso de la República de Colombia, Ley 975 (Ley de Justicia y Paz), 2005.

13 Congreso de la República de Colombia, Ley 1448 (Ley de Víctimas y Restitución de Tierras). 
rebel group. ${ }^{14}$ Thus, the case study showed that jus post bellum applies because of the function it plays in the transition from armed conflict to peace, rather than to a specific moment of such a transition. ${ }^{15}$

Fourth, jus post bellum is a matter of international law, even regarding NIAC s. ${ }^{16}$ Jus post bellum has been mainly developed in relation to IACs, in which the norms involved are international. So far, the few works addressing jus post bellum in NIAC ${ }^{17}$ have not analyzed the concrete application of legal norms. However, even though jus post bellum involves the interaction of international and domestic law, ${ }^{18}$ it is based on international law. There are at least three reasons explaining this argument in the context of NIACs. First, the transition from armed conflict to peace became a matter of international legal interest because it relates to international values such as human rights, justice, and the rule of law. Second, in a global legal world, states are bound by several international obligations covering most of the matters treated in peace processes. Third, and possibly the most substantial reason, because of the intrinsic asymmetry between the state and the non-state actors involved in a NIAC, domestic law would hardly be seen as an impartial framework to hold peace negotiations, and non-state actors would be more reluctant to accept conditions derived from the institutional order they are fighting against.

In conclusion, considering the elements discussed above, jus post bellum can be understood as a normative framework of principles-grouping legal norms, discourses, and practices - that offers a space of contextualized interpretation and application of relevant international law to the transition from armed conflict to sustainable peace. This framework offers guidance on the standards that should be observed, but its precise content is built through the practice of actors involved in transitional processes, in the way they integrate, interpret, and apply international legal norms, discourses, and practices

14 As seen in Chapter 2, the ELN guerilla keeps in armed confrontation in Colombia. See Chapter 2, Section o.

15 See Chapter 1, Section 3, on the discussion on the temporal or fuctional approach to jus post bellum.

16 Even though existing definitions do not explicitly describe jus post bellum as being international law, all of them refer to international legal norms. However, in a literature review on peacebuilding, Chetail and Jütersonke refer to a previous Chetail's article to define jus post bellum as "norms of international law that are applicable in a post-conflict environment." Chetail and Jütersonke, 'Peacebuilding: A Review of the Academic Literature,' 5.

17 See Introduction, Section 4.

18 See, for instance, Stahn, 'Jus Post Bellum: Mapping the Discipline(s),' 2008, 102; Payne, 'The Norm of Environmental Integrity in Post-Conflict Legal Regimes,' 118. Easterday, 'Peace Agreements as a Framework for Jus Post Bellum,' 380. 
from other processes to their specific context. As such, the principles comprising jus post bellum are in permanent evolution, incorporating new rules, discourses, and practices according to the dynamics of the actors involved in the application and creation of law through peacemaking and peacebuilding.

Jus post bellum is a framework in continual development. Sari sustains that conceiving jus post bellum as a normative process "rather than just as a set of norms, emphasizes that the legal standards applicable in post-conflict environments are not static but evolutionary. This is both a factual and a normative claim."19 Indeed, theory and practice coincide in demonstrating that the complexity and context-specificity of transition from armed conflict to peace require a level of flexibility that cannot be provided by an imperative legal regime. Instead, jus post bellum should offer a framework containing legal constraints, possible options, and guidelines for parties to make their own normative decisions. Thus, it is a process of continual construction involving both the application and creation of new norms. ${ }^{20}$

In Kastner's words, "Law shapes peace negotiations, and peace negotiations generate legal normativity"21 This is so since norms and obligations associated with transition "are rooted in the social interaction between the actors involved and are constantly reassessed and renegotiated." ${ }^{22}$ In this sense, more than prescriptive, these norms are "purposive and aspirational in character."23

This idea is expressed more generally by Brunée and Toope, who sustain that "law can help to shape interactions in international society, and is in turn modified by those interactions." ${ }^{24}$ Following Fuller, this is due to the fact that law is a process, and legal norms are never a completed project. ${ }^{25} \mathrm{On}$ this topic, Bell points out that,

\footnotetext{
19 Sari, 'The Status of Foreign Armed Forces Deployed in Post-Conflict Environments: A Search for Basic Principles,' 5oo.

$20 \quad$ Kreß and Grover, 'International Criminal Law Restraints in Peace Talks to End Armed Conflicts of a Non-International Character,' 46.

21 Kastner, Legal Normativity in the Resolution of Internal Armed Conflict, 182.

22 Kastner, 2.

23 Kastner, 3.

24 Jutta Brunnée and Stephen Toope, Legitimacy and Legality in International Law: An Interactional Account (Cambridge: Cambridge University Press, 2010), 354.

25 Lon Fuller, The Morality of Law (New Heaven: Yale University Press, 1969), 106, as referred by Kastner, Legal Normativity in the Resolution of Internal Armed Conflict, 32.
} 
$[\mathrm{P}]$ eace agreements can be argued to have evolved and shaped the same international legal developments that promoted them as a conflict resolution tool [...] The relationship of international law to peace agreements cannot be simply pulled apart as one of cause and effect. [...] [P]eace agreements as legalized documents shape not just particularized conflicts but also the international legal order itself. ${ }^{26}$

This double process of normative application and creation of law is given by the fact that the practice of peace negotiations involves taking elements from applicable international law as well as from comparative practice in other processes, and adapting these elements to the concrete context, generating new forms of interpretation and application of the corresponding norms. Kastner notes that through their discourses and practices, "the respective actors constantly create and redevelop the legal-normative framework of peace negotiations. While crafted in a specific context, this framework is not entirely spontaneous or selfsufficient but influenced by international legal norms and the experiences and lessons from other peace negotiation contexts." 27

At least three examples from the peace negotiations in Colombia can illustrate the formative process of jus post bellum. One is the use given by the parties to the IHL's mechanism of special agreements and to unilateral declarations before the UN to provide legal certainty to the peace agreement. Given that there is no specific legal regulation on the normative status of domestic peace agreements, the parties took elements from international positive law and practice to declare the international legal character of their peace agreement. This will likely serve as a precedent for other peace processes around the world.

A second example is the way in which the transitional justice model was created, taking legal discourses and legal practices to interpret and apply relevant legal obligations. The statements by the Office of the ICC Prosecutor, UN agents and civil society organizations, and previous rulings of the Constitutional Court created a framework on the scope, limits, and possibilities of interpreting and applying both the IHL's provision on amnesties at the end of armed conflict and the ICL's prohibition on those amnesties regarding serious international crimes.

The third example is the inclusive approach of the peace process that expanded the mandate of UNSC Resolution 1325 on women's participation and

26 Bell, On the Law of Peace, 44-45.

27 Kastner, Legal Normativity in the Resolution of Internal Armed Conflict, 83-84. 
inclusion to other groups such as LGBTI and ethnic peoples, as the result of strategic advocacy by human rights organizations. This advocacy was based on international law, drawing on positive and soft law instruments to build a discourse defending inclusiveness as a legal obligation rather than a political choice.

All three examples illustrate how the confluence of legal norms, discourses, and practices, which involved different actors at different levels, formed and operated a framework to coordinate, interpret, and apply legal normativity that was not specifically designed for transitional contexts. Such a framework is jus post bellum.

Based on this logic, in the transition from armed conflict to peace international law does not work by imposing external imperative norms on the parties. On the contrary, it works as a framework providing guidance on the issues to address and the rights that must be respected, allowing the parties to devise their own way of dealing with them. This process implies a new vision of the role of international law and its interaction with domestic transition. According to Kastner,

The still-prevalent emphasis on existing international law that is seen as imposing rigid standards and a certain conduct from 'above' should be supplanted by the view that law can also facilitate, offer guidance, reflect mutual commitments and serve to stabilize expectations. [...] Recognizing the norm creative capacity of the actors involved in peace negotiations is one avenue to use legal norms more constructively and effectively in the context of the negotiated resolution of internal armed conflicts. $^{28}$

Along this line, then, "the legal obligations operate, again, rather as 'framework' obligations whose precise normative content must be specified in every context." ${ }^{29}$ This is evident in the Colombian transition. General international legal obligations defined a framework on the fundamental issues that the parties had to consider, as well as the rights and conditions to be ensured. ${ }^{30}$ Additionally, legal discourses and comparative practices on these matters demarcated the ways and conditions in which to apply those norms. However, such a framework was opened to the concrete requirements of the context.

28 Kastner, $83-84$.

29 Kastner, 169.

$30 \quad$ E.g.: the prohibition on amnesties for international crimes and victim's rights, as presented in Chapter 2. 
The parties understood that they had to find a way to balance international legal obligations with the political needs of peace. In this way, such a process, in which the parties negotiated and defined formulas aimed at establishing sustainable peace in their concrete context, expresses how jus post bellum works in practice.

\section{$3 \quad$ Principles of Jus Post Bellum Identified in the Colombian Case}

As discussed in Chapter 1, most authors working on jus post bellum have proposed principles as the way to define the content of the concept. For Stahn, jus post bellum should allow the identification of normative principles guiding "legal policy choices in situations of transition." ${ }^{31}$ Easterday refers to overarching principles "focused on sustainable peace against which laws and policies can be interpreted." ${ }^{2}$ De Brabandere understands the concept as "a normative set of principles" based on existing international law to interpret applicable "rules in function of the identified overarching principles."33 And though Bell does not use the concept of jus post bellum, she advocates for a "set of programmatic standards that provide guidance [...] as to how the dilemmas of peace $[. .$.$] can be resolved concomitantly with the requirements of interna-$ tional law." 34

Following the above views, and as discussed in Chapter 1, it can be concluded that principles are the substantive content of jus post bellum. May suggests six principles: building and rebuilding, retribution, restitution, reparation, reconciliation, and proportionality. ${ }^{35}$ His proposal is endorsed by the University of Leiden's Jus Post Bellum Project as a solid basis for defining the content of the concept. $^{36}$

Regarding this matter in NIACs, Boon argues that there are at least two kinds of principles of jus post bellum. ${ }^{37}$ One kind entails principles guiding matters governed by IHRL, IHL, and ICL, where international law establishes

\footnotetext{
31 Stahn, 'Jus Post Bellum: Mapping the Discipline(s),' 2008, 101-2.

32 Easterday, 'Peace Agreements as a Framework for Jus Post Bellum,' 385.

33 De Brabandere, 'The Concept of Jus Post Bellum in International Law: A Normative Critique,' 137 .

34 Bell, 'Of Jus Post Bellum and Lex Pacificatoria: What's in a Name?,' 192.

35 May, After War Ends, 5 .

36 Easterday, Iverson, and Stahn, 'Exploring the Normative Foundations of Jus Post Bellum: An Introduction,' 1; Stahn, 'Jus Post Bellum and the Justice of Peace: Some Preliminary Reflections.'

Boon, 'The Application of Jus Post Bellum in Non-International Armed Conflicts.'
} 
more exigent standards to observe. Another kind referts to principles guiding matters such as socio-economic reconstruction and institutional design, where international law provides only general elements, giving greater leeway to the parties in defining their own formulas.

Having these elements, this section explores the principles of jus post bellum in the Colombian case. Toward this aim, we depart from May's proposal (because they are the most widely accepted principles among scholars working in this field) but reformulate some of his principles, uses references to other authors' principles, and adds new ones. Furthermore, this section will consider Boon's proposal on the scope of these principles in the context of NIACs. In any case, it is important to make clear that the principles referred to in this section are far from being exhaustive, and other matters are susceptible to be also considered as principles. However, this selection expresses the components of the Colombian transition that were most influenced by international legal considerations, and, consequently, closer to the purpose of illustrating an international normative framework guiding transitions through general normative principles.

\subsection{Reconstruction and Transformation}

May argues that there is an obligation to rebuild the capacity to protect human rights and to promote the rule of law, as well as to build such a capacity where it did not exist prior to the conflict. ${ }^{38}$ In a similar approach, Patterson formulates this principle as order, including the obligation to ensure security needs, the guarantee of rights, and reconstruction both in terms of infrastructure damaged by armed conflict and institutional capacities. ${ }^{39}$ Williams and Caldwell also discuss the restoration of order and economic reconstruction from a human rights perspective. ${ }^{40}$ For them, jus post bellum should lead to a peace where human rights "are more secure than they were before war."41 Also on this topic, Orend proposes a principle of rehabilitation of the capacities affected by conflict, ${ }^{42}$ Coady a principle of rebuilding and reconstruction, ${ }^{43}$

38 May, After War Ends, 19.

39 Eric Patterson, 'Conclusion. Toward a Twenty-First Century Jus Post Bellum,' in Ethics Beyond War's End, ed. Eric Patterson (Washington: Georgetown University Press, 2012), 221-29.

40 Williams and Caldwell, 'Jus Post Bellum: Just War Theory and the Principles of Just Peace,' 318.

41 Williams and Caldwell, 316.

42 Orend, 'Jus Post Bellum: A Just War Theory Perspective,' 38-41.

43 Coady, 'The Jus Post Bellum.' 
and De Brabandere a principle of reconstruction for the benefit of the population. ${ }^{44}$

This principle embodies two kinds of obligations: first, the obligation to reconstruct physical infrastructure and institutional capacities affected during the hostilities; and second, the obligation to address the root causes of conflict and transform the conditions that led to armed confrontation. As such, the principle conveys the idea of both reconstruction and transformation. The principle calls for a certain level of restoration of the status quo ante, ${ }^{45}$ but it also calls for transformation when that status quo was the very cause of the conflict, as it is often the case in NIACs. On this line, Kastner sustains that internal peace "negotiations typically introduce novelty, seeking not to reestablish but to alter the status quo ante."46

This principle is related to the notion of positive peace. ${ }^{47}$ Jus post bellum looks at integrating standards not only for ending conflict but also for creating or recovering the conditions to ensure an adequate level of living. ${ }^{48}$ As pointed out by Chetail, peacebuilding means "to free individuals not only from 'fear' but also from 'need,",49 and Benson refers to "post-conflict economic reconstruction and development" as a central goal of jus post bellum..$^{50}$ In that way, peace negotiations and peace agreements represent an opportunity for discussing and addressing structural issues in society, ${ }^{51}$ and then this principle embodies such an opportunity also as a legal obligation. ${ }^{52}$

In this way, this principle offers a space to integrate international legal obligations into the political and socio-economic structure of transition. Looking at the Colombian experience, the principle is expressed in the way in which the parties conceived the agenda of peace negotiations. The objective was not only to end armed confrontation but also to address its structural causes. As seen in Chapter 2, Colombia comprehensively addressed matters such as

44 De Brabandere, 'The Concept of Jus Post Bellum in International Law: A Normative Critique,' $137-38$.

45 Bass, 'Jus Post Bellum,' 384.

46 Kastner, Legal Normativity in the Resolution of Internal Armed Conflict, 6.

47 Galtung, 'Violence, Peace, and Peace Research.'

48 See Chapter 1, Section 4, on the object of jus post bellum.

49 Chetail, 'Introduction,' 8.

50 Christina Benson, 'Jus Post Bellum in Iraq: The Development of Emerging Norms for Economic Reform in Post Conflict Countries,' Richmond Journal of Global Law \& Business 11, no. 4 (2012): 350-51.

51 Bell, Peace Agreements and Human Rights, 229-30; Easterday, 'Peace Agreements as a Framework for Jus Post Bellum,' 401-4.

$5^{2}$ See Chapter 2, Section 2.1., on the legal framework related to socioeconomic and political reforms in transition from armed conflict to peace. 
socioeconomic rural development, alternatives to crops of illicit use, political participation, and opportunities for new political expressions, among others. ${ }^{53}$ The lack of these conditions has been considered a root cause of the conflict, ${ }^{54}$ making clear that for the parties such an element was a departing point to envisage a sustainable peace.

Following Boon's proposal, this is one of the principles of jus post bellum regarding which international law can only offer general guidelines, leaving the parties enough margin of appreciation to define their own arrangements. The 2016 Colombian Peace Agreement exhibits a deep grounding on international law in all its matters, including references to the international framework on economic, social, and cultural rights to adopt socioeconomic and political reforms, ${ }^{55}$ but the concrete formulas on this matter were mostly based on policy and domestic law. ${ }^{56}$

Here, one can see the parties' understanding of the existence of international legal obligations guiding socioeconomic, political, and institutional affairs, and their will to ground reforms on those matters on such an international legal framework. However, unlike other components of the negotiation, in this matter the parties did not follow a clear legal standard but responded to the concrete causes and circumstances of armed conflict in Colombia. For example, the parties agreed on formulas on rural development or political participation, framing them under international law, but the specific measures on land access, reintegration programs, or the conditions for the creation of a political party were primarily policy-based. However, it is worth to note how the references to international law as a framework for the negotiations on those matters gave a human-rights-based approach to socioeconomic and political reforms.

As such, the Colombian experience displays reconstruction and transformation as an authentic normative principle of jus post bellum. In this way, the political discussions around addressing the root causes of armed conflict, implementing socioeconomic and political reforms, and promoting reintegration of former fighters and rural development, had an international legal framework of reference guiding relevant actors in their negotiation and definition of formulas according to the needs and conditions of their context. Then,

53 See Chapter 2, Section 2.2.

54 Government of Colombia and Farc, 'Final Agreement to End the Armed Conflict and Build a Stable and Lasting Peace,' 2.

55 Government of Colombia and FARC, 199.

56 Government of Colombia and FARC, 125, 134, 199. 
this principle offers a normative space of discussion on matters that by their nature are more a question of policy and socioeconomic debate.

\subsection{Criminal Accountability}

May refers to this principle as retribution, denoting criminal justice for wrongdoings during armed conflict. ${ }^{57}$ However, since retributive justice is not the most common form of justice in contexts of transition, this principle can be better named as criminal accountability. This principle is proposed by most authors in the field, even though different terms are used. Stahn talks about individual responsibility for wrongs committed during the conflict. ${ }^{58}$ Orend, ${ }^{59}$ Coady, ${ }^{60}$ and Willians and Caldwell ${ }^{61}$ refer to the principle as punishment for human rights violations. Gallen, ${ }^{62}$ De Brabandere, ${ }^{63}$ and Boon ${ }^{64}$ refer to a principle of accountability.

As pointed out by May, trials constitute a fundamental step in restoring the rule of law. ${ }^{65}$ However, in transitions from conflict to peace, this principle should be understood as the exigency of a certain form of justice, though not necessarily a retributive one. ${ }^{66}$ Affirming this idea, May later sustained that "the justice of jus post bellum is secured not through giving to people what is their due in the short run, but in securing what is good for societies that seek to return to a lasting peace." 67

This perspective expresses the nature and function of jus post bellum principles. Though criminal accountability is a fundamental component of transition from conflict to peace, the levels and forms of criminal justice must be determined through balancing this duty with other principles of jus post bellum. On this point, Peperkamp claims that the moral and legal obligation of punishment should not prevail over the concrete needs of peace, even if there is no agreement on what should be the outcome of this collision of

57 May, After War Ends, 20.

$5^{8}$ Stahn, “Jus Ad Bellum", "jus in Bello" ... "Jus Post Bellum"? — Rethinking the Conception of the Law of Armed Force,' 938-41.

59 Orend, 'Jus Post Bellum: A Just War Theory Perspective,' 38-41.

6o Coady, 'The Jus Post Bellum.'

61 Williams and Caldwell, 'Jus Post Bellum: Just War Theory and the Principles of Just Peace.'

62 Gallen, 'Jus Post Bellum: An Interpretive Framework.'

63 De Brabandere, 'The Concept of Jus Post Bellum in International Law: A Normative Critique,' $137-38$.

64 Boon, 'Legislative Reform in Post-Conflict Zones: Jus Post Bellum and the Contemporary Occupant's Law-Making Powers.'

65 May, After War Ends, 78.

66 May, 'Reparation, Restitution, and Transitional Justice,' 39.

67 May, 'Jus Post Bellum, Grotius, and Meionexia,' 21. 
values. ${ }^{68}$ May warns that one of the problems of this principle "is that since retribution is backward-looking and most of the other jus post bellum principles are forward-looking, pursuit of a just and lasting peace tends to favor the forward-looking principles." ${ }^{69}$ Bass and Walzer even claim that the duty of peace and reconciliation prevails over the duty of justice. ${ }^{70}$

Looking at those elements, it is here where principles offer a space of coordination and balance for interpreting and applying legal obligations consistently with respect to the exigencies of peace. As seen in Chapter 2, criminal justice is one of the most sophisticated components of the Colombian Peace Agreement. ${ }^{71}$ Since 2005 Colombia developed a system of transitional justice for the demobilization of paramilitary groups, which offered an innovative way to reconcile the requirements of international law with the practical needs of peace. The Justice and Peace Law balanced the prohibition on amnesties for serious violations of human rights and IHL against the fact that members of armed groups in negotiation would not accept regular criminal sanctions. ${ }^{72}$ Thus, such a law established a system of justice in which those responsible for the most serious crimes were tried and sentenced, but given reduced penalties in exchange for their contribution to peace.

In the 2012-2016 peace negotiations, the conditions were more complicated. Unlike paramilitary groups, the guerilla claimed the political character of their fight, and as such they were not willing to accept the same conditions that were offered by the 2005 Justice and Peace Law. As seen in Chapter 2, the guerrilla was even resistant to including an item on justice in the agenda of negotiations. ${ }^{73}$ However, as they accepted a chapter on victims, they understood that criminal justice was a victim's right and an exigence of international law. Here, again, a discussion on the balance between peace and justice emerged. And this is where jus post bellum offers a space of coordination and interpretation: a principle of accountability, including criminal responsibility, exists in international law and is a necessity in peace negotiations; however, the conditions of the context require it to be interpreted and applied according to the specific needs of peace.

68 Peperkamp, 'Jus Post Bellum: A Case of Minimalism versus Maximalism?,' 261.

69 May, After War Ends, 79.

70 Bass, 'Jus Post Bellum,' 405; Walzer, 'The Aftermath of War. Reflections on Jus Post Bellum,' 45 .

71 See Chapter 2, Section 3.3.

72 See Chapter 2, Section 3.3.1.

73 See Chapter 2, Section 3. 
In this case, new elements emerged for the interpretative balance. Colombia had the precedent of the 2005 system of reduced penalties. As examined in Chapter 2, the final version of that law was the result of different actors' claims around the international legal prohibition on amnesties for serious crimes. The parties in the 2012-2016 peace process departed from the fact that no amnesty was possible for those crimes. However, the guerilla was not willing to accept any kind of prison sanctions. At the same time, the Office of the ICC Prosecutor insisted on the obligation to prosecute serious crimes committed during the conflict. Furthermore, the Prosecutor added a new element specifying that even if restorative sanctions were possible in the context of a peace process, they should include effective restrictions on liberty. All these elements finally carried out a Special Jurisdiction for Peace tasked with investigating and trying people responsible for the most serious crimes. These individuals should fully cooperate with truth and reparation, and in exchange they will receive restorative sanctions accompanied by effective restrictions on liberty as defined by their judges.

As such, compared to the other principles, for the principle of criminal accountability international law sets stronger standards and exigences that must be observed in the transition from armed conflict to peace. This is in accordance with Boon's argument that in matters dealing with past human rights and IHL violations, principles offer a lower margin of appreciation to the parties.

Therefore, in the way this principle worked in Colombia, we can see a clear example on the role of international law as a framework offering to the parties limits and possibilities, expressed in legal norms, discourses, and practices, in which they moved to create a transitional justice model concilitating the exigences of international law with their practical needs of peace.

\subsection{Reparation}

Contemporary armed conflicts occur in a way such that civilians suffer most of the damages caused by the confrontation. NIAC s usually entail degradation of violence, where forced displacement, killings, sexual violence, enforced disappearance, and many other violations of human rights and IHL occur. This situation evinces the state's failure to fulfill its international obligation of respecting and guaranteeing the rights of its people. Therefore, the legal obligation to provide reparation for these damages emerges. ${ }^{74}$ 
On this issue, May proposes the principles of restitution and reparation, while Stahn ${ }^{75}$ and Coady ${ }^{76}$ propose just reparation, and Orend compensation. ${ }^{77}$ For May, "restitution is the restoring to the rightful owner what has been lost or taken away," whereas "reparation is the restoring to good condition of something that has been damaged." ${ }^{78}$ In any case, both concepts are grounded in the idea of restoration, which he defines as "a kind of rectification or compensation."79 However, such a distinction appears unnecessary as restitution is a modality of reparation. This is the view of the UN Basic Principles and Guidelines on the Right to a Remedy and Reparation for Victims, Principle 18 of which states:

In accordance with domestic law and international law, and taking account of individual circumstances, victims of gross violations of international human rights law and serious violations of international humanitarian law should, as appropriate and proportional to the gravity of the violation and the circumstances of each case, be provided with full and effective reparation [...], which include the following forms: restitution, compensation, rehabilitation, satisfaction and guarantees of non-repetition. ${ }^{80}$

The victim's right to reparation is enshrined in several instruments under I HRL, IHL, and ICL. ${ }^{81}$ However, as mentioned in the previous paragraph, reparations must take consideration of the specific circumstances in which the violations of human rights or IHL have occurred. This is especially the case in the context of armed conflict, where victimization is widespread and is committed by different state and non-state actors. ${ }^{82}$ This principle thus offers the space and

75 Stahn, “"Jus Ad Bellum”, "jus in Bello” ... “Jus Post Bellum"?-Rethinking the Conception of the Law of Armed Force,' 938-41.

76 Coady, 'The Jus Post Bellum.'

77 Orend, 'Jus Post Bellum: A Just War Theory Perspective,' 37-42.

78 May, After War Ends, 183.

79 May, 'Reparation, Restitution, and Transitional Justice,' 32.

8o UN General Assembly, Basic Principles and Guidelines on the Right to a Remedy and Reparation for Victims of Gross Violations of International Human Rights Law and Serious Violations of International Humanitarian Law.

81 See Chapter 2, Section 4.1., for the international legal framework on reparations.

82 At this regard, the International Law Association has proposed two resolutions on the specific conditions of reparation for victims or armed conflict, in an effort to advance the discussion on the issue both in substantive and procedural terms. International Law Association, Draft Declaration of International Law Principles on Reparation for Victims of Armed Conflict; International Law Association, Draft Procedural Principles For Reparation Mechanisms. 
the elements to coordinate and interpret international standards vis-à-vis the concrete circumstances of a given transitional scenario.

The principle of reparation has been a core element in the Colombian transition. As seen in Chapter 2, in 2011 the country adopted what is internationally considered the most developed system of comprehensive reparations to victims of armed conflict. ${ }^{83}$ Such a milestone imposed on the parties involved in the 2012-2016 peace process the duty of placing victims at the center of the negotiation. ${ }^{84}$ The awareness regarding this principle of reparation in Colombia has been a significant element in developing the negotiations and is reflected in the Final Agreement. Additionally, the aim to grant remedies to victims led the parties to include other elements in the Agreement, through the development of a comprehensive system of truth, justice, and reparations. ${ }^{85}$

The principle of reparation in Colombia has played a vital role in transition, and this case offers insightful elements for other transitional contexts around the world. Reparation for victims of armed conflict is a must not only as a legal duty under international law, but as a condition to make peace sustainable and reconciliation effective. From this case, one can conclude that the normative principle of reparation has a solid international legal basis as well as valuable comparative practice showing to actors involved in trasitions the way to make reparation possible and effective, following international standards and considering the limits and conditions imposed by their context. Additionaly, an important contribution of the Colombian approach is given by the way in which it addresses reparations by non-state actors. As seen in Chapter 2, international law and legal scholarship are increasingly discussing this matter, and practice from Colombia will certainly offer new insights, mainly regarding the role of reparation by those actors whitin the judicial process before the Special Jurisdiction for Peace, as well as beyond judicial mechanisms through acts of public apologies and contribution to truth and reconciliation.

\subsection{Reconciliation}

The principle of reconciliation expresses the main political challenge of peacemaking and peacebuilding. It is aimed at bringing people together to

83 Unidad de Atención y Reparación a Víctimas, Universidad de Harvard destaca Política Integral de Reparación de Víctimas en Colombia, 2015, available at: http://www.unidadvictimas.gov. co/es/valoraci\% $\mathrm{C}_{3} \% \mathrm{~B}_{3}$-y-registro/universidad-de-harvard-destaca-pol\% $\mathrm{C}_{3} \% \mathrm{ADtica}-$ integral-de-reparaci $\% \mathrm{C}_{3} \% \mathrm{~B}_{3} \mathrm{n}-\mathrm{de}-\mathrm{v} \% \mathrm{C}_{3} \% \mathrm{ADctimas}-\mathrm{en}$ (accessed on 1 April 2018).

84 Government of Colombia and FARC, 'Final Agreement to End the Armed Conflict and Build a Stable and Lasting Peace,' 8.

85 Government of Colombia and FARC, 132. 
live peacefully, which is an expression of sustainable peace. ${ }^{86}$ Reconciliation seeks "to create relationships of respect, trust, and friendship," 87 as well as to "bring emotional healing to the victims of war." ${ }^{8}$ However, as May argues, "the jus post bellum principle of reconciliation is often one of the hardest things to achieve," as it involves a modus vivendi in which people are able to not only respect each other but also reach cooperation. ${ }^{89}$ This principle is equally proposed by $\mathrm{Stahn}^{90}$ and by Patterson. ${ }^{91}$

Due to its highly political content, this principle is the most difficult to delineate in a legal perspective. May says that reconciliation is often viewed as "too amorphous a category to count as jus post bellum normative principle." Nonetheless, the principle of reconciliation can find different legal bases. First, it is an expression of the state's general obligation to promote peaceful societies and ensure respect for people's rights. ${ }^{93}$ Second, reconciliation is a condition to guarantee the non-repetition of human rights violations, which embodies the positive obligations of prevention and reparation. ${ }^{94}$ And, third, reconciliation is closely related to the right to truth, both for victims and society. ${ }^{95}$

Based on these considerations, the principle of reconciliation attains legal value. Although reconciliation seems more a goal of transition than a principle guiding the coordination and interpretation of legal norms, such a goal

86 See Chapter 1, Section 4, for the discussion on the role of reparations as part of the object of jus post bellum in building a sustainable peace.

87 Peperkamp, 'Jus Post Bellum: A Case of Minimalism versus Maximalism?', 269.

88 Mark Allman and Tobias Winright, After the Smoke Clears: The Just War Tradition and Post War Justice (New York: Orbis, 2010), 102.

89 May, After War Ends, 75 .

9o Stahn, “"Jus Ad Bellum”, “jus in Bello" ... “Jus Post Bellum"?-Rethinking the Conception of the Law of Armed Force,' 938-41.

91 Eric Patterson, Ending Wars Well: Order, Justice, and Conciliation in Contemporary PostConflict (New Haven: Yale University Press, 2012), 102.

92 May, After War Ends, 85 .

93 UN General Assembly, Declaration on the Right to Peace; International Covenant on Civil and Political Rights Art. 2.

94 Inter-American Court of Human Rights, Case of the Massacres of El Mozote and nearby places v. El Salvador, Judgement of 25 October 2012 Concurrent Opinion Judge Diego García-Sayán et. al., para. 23. See also Juana Acosta-Lopez, 'The Inter-American Human Rights System and the Colombian Peace: Redefining the Fight Against Impunity,' American Journal of International Law 110 AJIL Unbound Symposium on the Colombian Peace Talks and International Law (2016): 179 .

95 UN Commission on Human Rights, 'Study on the Right to the Truth, Report of the Office of the United Nations High Commissioner for Human Rights,' Pub. L. No. E/CN.4/20o6/ 91 (2006); Yasmin Naqvi, 'The Right to the Truth in International Law: Fact or Fiction?,' International Review of the Red Cross 88, no. 862 (2006): 245-73. 
is present in the process of balancing legal obligations against the political needs and aims of peace. In other words, if reconciliation is a condition necessary for building sustainable peace, it becomes a crucial consideration for the application of the normative framework of jus post bellum, and any measure or instrument designed for transition should contribute to that aim of social reconciliation. Therefore, reconciliation is a principle of jus post bellum.

Reconciliation has been a vital principle in the Colombian transition. In the recent peace process, this principle is expressed in several ways. Addressing the root causes of the conflict related to inequality and political exclusion contributes to reconciliation. ${ }^{96}$ The search for truth is a measure aimed at healing people and rebuilding the social fabric. The reparation of victims is also a reconciliation-oriented measure, including actions of reparation by non-state armed actors. ${ }^{97}$ Similarly, the mechanism of restorative sanctions for those responsible for serious crimes-which included contributing to rural development and demining as well as participating in social programs-is aimed at integrating former fighters into their communities to foster peaceful coexistence..$^{98}$ All of these aims could be considered to be playing a role in balancing international legal requirements with the interests of the parties and the expectations of victims and society as a whole.

Nevertheless, the political dimension of this principle does not allow international law to define specific conditions or standards, but general elements for guiding parties in the transition. Here, in accordance with Boon's proposal, there is a general obligation for states to promote peaceful coexistence and rebuild the social fabric after armed conflict, responding to the jus post bellum's objective of attaining sustainable peace, but it must be met in accordance to the concrete conditions of the context. However, from the case study one can see how this principle has a normative standing to be integrated not only as a goal, but also as component of the normative framework guiding the legal and political decisions for transition to peace.

\subsection{Proportionality}

This principle has the larger consensus among authors. Alongside May, Orend, Gallen, De Brabandere, and Boon include proportionality as a principle of jus

96 See Chapter 2, Section 2.2. on socioeconomic and political reforms included in the Peace Agreement in Colombia for addressing the root causes for armed conflict.

97 See Chapter 2, Section 4.2. on the approach to reparations in the Colombian transition.

98 See Chapter 2, Sections 2.2 and 3.3 on the mechanisms of transitional justice in Colombia, and how restorative santions play also a role in the social reintegration of former rebels. 
post bellum. ${ }^{99}$ May describes proportionality as a "meta-principle" over the others. In his words, proportionality "urges that we think about the harm that is caused by the post war application of the other normative principles. In this way, the proportionality principle could be written into each of the principles as a modification of them." ${ }^{100}$ The idea behind proportionality is "to consider whether the operation of these other post bellum principles might not do more harm than good." 101

Proportionality is a general requirement of international law that can be considered to be implicit in the other principles of jus post bellum. However, it has relevance in jus post bellum as long as it guides the parties' balances and decisions within the bargaining zone defined by the other principles. For instance, proportionality plays a role in defining the balance between the retributive dimension of criminal responsibility required by ICL and the need to adopt a restorative approach in a transitional process. ${ }^{102}$ On this point, the following analysis presented in a concurrent opinion of an Inter-American Court of Human Rights' judgement is relevant:

38. Thus, in certain transitional situations between armed conflicts and peace, it can happen that a State is not in a position to implement fully and simultaneously, the various international rights and obligations it has assumed. In these circumstances, taking into consideration that none of those rights and obligations is of an absolute nature, it is legitimate that they be weighed in such a way that the satisfaction of some does not affect the exercise of the others disproportionately. Thus, the degree of justice that can be achieved is not an isolated component from which legitimate frustrations and dissatisfactions can arise, but part of an ambitious process of transition towards mutual tolerance and peace. ${ }^{103}$

This principle of proportionality is expressed in different components in the Colombian transition. For instance, regarding criminal responsibility,

99 Boon, 'Legislative Reform in Post-Conflict Zones: Jus Post Bellum and the Contemporary Occupant's Law-Making Powers'; Orend, 'Jus Post Bellum: A Just War Theory Perspective'; May, After War Ends; Gallen, 'Jus Post Bellum: An Interpretive Framework'; De Brabandere, 'The Concept of Jus Post Bellum in International Law: A Normative Critique.'

100 May, After War Ends, 22.

101 May, 'Jus Post Bellum, Grotius, and Meionexia,' 18.

102 See Chapter 2, Section 3.3.

103 Inter-American Court of Human Rights, Case of the Massacres of El Mozote and nearby places v. El Salvador, Judgement of 25 October 2012 Concurrent Opinion of Judge Diego García-Sayan, suscribed by four of the seven judges, para. 38 . 
the parties balanced ICL's exigences and the ICC Prosecutor's messages on the need to impose effective restrictions of liberty, on the one hand, against the practical need of offering restorative rather than retributive sanctions after a peace negotiation, on the other. As a result, the parties found an intermediate formula that established formal trials and judicial sanctions alongside restorative measures accompanied by restrictions of liberty. This was the result of a proportional balance between legal standards, values, and political requirements of peacemaking. Another example can be seen in the component of reparations, for which international legal standards needed to be measured against the extensive number of victims requiring reparation. ${ }^{104} \mathrm{~A}$ proportional balance was thus required that took into account the comprehensive approach to reparations established by international law, the number of victims, and the State's financial constraints, giving as a result an administrative system of comprehensive reparations offering standard measures according to the kind of damage suffered by the victims. In this way, balances of proportionality from the case study offer elements and examples on how this principle works as a component of the normative framework for transition and how it could be applied in other contexts.

\subsection{Inclusiveness}

The broad participation of different social sectors, as well as the consideration of their particular needs in peace processes and agreements, is gaining increasing importance around the world. As presented in Chapter 2, international law enshrines the right of traditionally marginalized groups to be consulted on issues of their interest, as it is the case of indigenous and tribal peoples. ${ }^{105}$ Similarly, the UN has consistently advocated for women's participation and inclusion in peace processes and agreements. ${ }^{106}$ Although this principle was not envisaged by May, practice provides elements for considering participation and inclusion as a principle of jus post bellum.

Stahn refers to this principle as "fairness and inclusiveness of peace settlements," arguing that sustainable peace requires all interests to be represented, including those of "groups and minorities protected by international law."107 Along the same line, Turner highlights that inclusion of groups such as women

\footnotetext{
104 See Chapter 2, Section 4.2.

105 See Chapter 2, section 5.1.2.

106 See Chapter 2, section 5.1.1.

107 Stahn, " "Jus Ad Bellum", "jus in Bello" ... "Jus Post Bellum"? —Rethinking the Conception of the Law of Armed Force,' 938.
} 
and indigenous peoples is being considered by parties in peace negotiations as a legal obligation. ${ }^{108}$

Ensuring specific participation in peace processes to certain groups is based on the idea that armed conflict does not impact all people in the same way. Different affected sectors should have a voice in peace negotiations and be differentially included in the resulting agreement. For this reason, this principle involves both a procedural and a substantive dimension. It is not just about granting participation in the peace negotiation process but also about ensuring that the specific needs of the involved sectors are adequately addressed in the peace agreement.

On this idea, Ní Aoláin and Haynes sustain that "countries emerging from conflict provide multiple opportunities for transformation on many different levels, opportunities uncommon in stable and non-transitional societies." ${ }^{109}$ For them, this opportunity is especially important for social groups traditionally "marginalized, underrepresented, and discriminated against."110 Transitional moments have great transformative potential, and this is why they must be made an opportunity to evaluate the situation of marginalized groups in society.

In this sense, this principle should be understood in a broad sense, as including the participation of victims and civil society as well as the specific interests of differential groups. Building sustainable peace after a NIAC does not only depend on the parties in conflict or the state. It must be the result of social dialogue involving a broad participation of different sectors. This is a crucial element for reaching lasting peace, ${ }^{111}$ increasing societal acceptance, and reducing the likelihood of excluded actors undermining the process. ${ }^{112}$ As such, it must be considered a jus post bellum principle guiding transition.

A principle of inclusiveness is notable in the Colombian peace process and its Final Agreement. As analyzed in Chapter 2, inspired by the UNSC Resolution 1325 on women's participation and inclusion in peace processes, Colombia devoted significant attention to women and gender issues in the

\footnotetext{
108 Catherine Turner, "Mapping a Norm of Inclusion in the Jus Post Bellum," in Just Peace After Conflict. Jus Post Bellum and the Justice of Peace, ed. Carsten Stahn and Jens Iverson (Oxford: Oxford University Press, 2020), 130-146.

109 Ní Aoláin and Haynes, 'The Compatibility of Justice for Women with Jus Post Bellum Analysis,' 161.

110 Ní Aoláin and Haynes, 161.

111 Anthony Wanis-St. John and Darren Kew, 'Civil Society and Peace Negotiations: Confronting Exclusion,' International Negotiation 13 (2008): 14.

112 Strengthening the Role of Mediation in the Peaceful Settlement of Disputes, Conflict Prevention and Resolution, Report of the Secretary-General, UN Doc. A/66/811 (25June 2012), Annex I, para. 29.
} 
negotiations. ${ }^{113}$ Following this path, the parties extended the gender dimension to LGBTI people, who also participated in the process and are referred to in the Agreement. Regarding ethnic minorities, the negotiators accepted the participation of indigenous and Afro-Colombian representatives, invoking ILO Convention 169 and other related instruments, and an ethnic chapter was included in the Agreement. ${ }^{114}$ Finally, under a victim-centered approach, a large delegation of victims participated in the negotiations, while other civil society actors were heard in different scenarios. ${ }^{115}$ In all of these cases, as exposed in Chapter 2, these social groups invoked international law to support their claims for participation and inclusion in the process. In this way, they were able to present the discussion on inclusiveness as not merely a question of legitimacy but an international legal requirement.

The experience in Colombia shows the normative power of this principle and it creates precedents for other processes around the world. Inclusiveness is a condition to make peace effective, sustainable, and transformative. As such, it cannot be left to the leeway of the parties, but it must be embodied as a normative principle for transition. Insightful elements are offered by this case study, and this principle can be considered as one of the most promising components of jus post bellum.

\subsection{Environmental Protection}

Armed conflict usually impacts the environment in different ways. In some cases, natural resources are exploited as a means to finance war, and in others, armed confrontation has direct or collateral effects on the environment. ${ }^{116}$ Thus, restoring and ensuring a healthy environment is a condition for building sustainable peace. ${ }^{117}$ Since 2014 Stahn has affirmed that jus post bellum needs to "encourage fresh thinking" on environmental damage related to armed conflict, ${ }^{118}$ which Easterday describes as a matter typically "ignored or superficially treated in peace agreements." ${ }^{119}$ Accordingly, Payne proposes a principle of environmental integrity as a component of jus post bellum, ${ }^{120}$ and the 2017 publication of the University of Leiden's Jus Post Bellum Project was devoted to

\footnotetext{
113 See Chapter 2, Section 5.2.3.

114 See Chapter 2, Section 5.2.3.

115 See Chapter 2, section 5.2.2.

116 Gillett, 'Eco-Struggles: Using International Criminal Law to Protect the Environment During and After Non-International Armed Conflict,' 223.

117 Stahn, 'Jus Post Bellum and the Justice of Peace: Some Preliminary Reflections,' 16.

118 Stahn, 'R2P and Jus Post Bellum. Towards a Polycentric Approach,' 118.

119 Easterday, 'Peace Agreements as a Framework for Jus Post Bellum,' 409.

120 Payne, 'The Norm of Environmental Integrity in Post-Conflict Legal Regimes.'
} 
the question of environmental protection and transition from armed conflict to peace. ${ }^{121}$

For Payne, the principle of environmental integrity ensures the soundness of natural resources, including human life and certain properties such as religious and cultural objects. ${ }^{122}$ She claims,

Three intertwined elements of jus post bellum are necessary to realizing environmental integrity. One is reparations, which provide means for reconstruction, create a record of what happened, and may provide disincentive for repetition of unlawful acts. A second is collective concern, which is a basis for community action on several fronts to contribute to reconstruction of war-torn states. The third is reconstruction itself. ${ }^{123}$

As analyzed in Chapter 2, damages to the environment can affect reconciliation, ${ }^{124}$ reconstruction, and socioeconomic development in post-conflict scenarios, ${ }^{125}$ making "environmental protection and the sustainable management of resources $[. .$.$] important pathways to consolidate peace and promote long-$ term development." ${ }^{126}$ For that reason, a principle of environmental protection must be part of jus post bellum, both in terms of the restoration of damages caused by armed conflict, ${ }^{127}$ and the promotion of the sustainable management of natural resources as a condition for lasting peace and development.

Regarding this issue, the ILC designated a Drafting Committee on the Protection of the Environment in Relation to Armed Conflicts, which

121 Stahn, Iverson, and Easterday, Environmental Protection and Transitions from Conflict to Peace: Clarifying Norms, Principles, and Practices.

122 Payne, 'The Norm of Environmental Integrity in Post-Conflict Legal Regimes,' 506. This broad view of environmental protection looks at overcoming the traditional anthropocentric frame given to environmental concern. Such an idea was later sustained by Payne in: Cymie Payne, 'Defining the Environment: Environmental Integrity', in Environmental Protection and Transitions from Conflict to Peace: Clarifying Norms, Principles, and Practices, ed. Carsten Stahn, Jens Iverson, and Jennifer Easterday (Oxford: Oxford University Press, 2017), 62.

123 Payne, 'The Norm of Environmental Integrity in Post-Conflict Legal Regimes,' 514.

124 Gillett, 'Eco-Struggles: Using International Criminal Law to Protect the Environment During and After Non-International Armed Conflict,' 249; Hofmann and Rapillard, 'PostConflict Mine Action: Environment and Law,' 404.

125 Easterday and Ivanhoe, 'Conflict, Cash, and Controversy: Protecting Environmental Rights in Post-Conflict Settings,' 274.

126 Hofmann and Rapillard, 'Post-Conflict Mine Action: Environment and Law,' 397.

127 Douglas Lackey, 'Postwar Environmental Damage: A Study in Jus Post Bellum; in International Criminal Law and Philosophy, ed. Larry May and Zachary Hoskins (Cambridge: Cambridge University Press, 2010), 141. 
elaborated a Draft Principles on the matter in 2016. Draft Principle 14 states that: "Parties to an armed conflict should, as part of the peace process, including where appropriate in peace agreements, address matters relating to the restoration and protection of the environment damaged by the conflict."128 This principle is drawn from different branches of international law related to environmental protection. ${ }^{129}$ It includes provisions from IHL, ${ }^{130}$ IHRL, ${ }^{131}$ and ICL. ${ }^{132}$

Having such a normative reference, the principle of environmental protection can be seen in different aspects of the Colombian Peace Agreement. ${ }^{133}$ As analyzed in Chapter 2, in its preamble the Agreement relates peace to sustainable development and the protection of the environment, natural resources, and biodiversity. ${ }^{134}$ Then, in the component on rural development, the Agreement discusses the "environmental rights of the rural population,"135 and offers special land access and other benefits to communities who work to protect the environment, substitute crops of illicit use, and improve food production. ${ }^{136}$ Similarly, the Agreement establishes the protection of areas of special environmental interest, seeking a sustainable development involving rural and ethnic communities. ${ }^{137}$ Furthermore, there are environmental protection-related provisions regarding the substitution of crops of illicit use and demining.

In this way, the Colombian case shows the negotiators' awareness on the duty to address environmental protection in their peace talks and to include related provisions in the Final Agreement. As such, this practice constitutes an expression of a jus post bellum principle of environmental protection in the

128 Report of the International Law Commission to the General Assembly, Seventy-first session, 2 May-10 June and 4 July-12 August 2016, UN Doc. A/71/10, http://legal.un.org/docs/ ?path=../ilc/reports/2016/english/a_71_10.pdf\&lang=EFSRAC, 309 .

129 Fleck, 'Legal Protection of the Environment. The Double Challenge of Non-International Armed Conflict and Post-Conflict Peacebuilding,' 203.

130 See, for instance, Henckaerts and Doswald-Beck, Customary International Humanitarian Law. Volume I: Rules. Rule 44.

131 See Report of the Special Rapporteur on the issue of human rights obligations relating to the enjoyment of a safe, clean, healthy and sustainable environment, A/HRC/31/53, 28 December 2015 .

132 Rome Statute of the International Criminal Court. Article 8(b)(iv).

133 See Chapter 2, Section 2.2.

134 Government of Colombia and Farc, 'Final Agreement to End the Armed Conflict and Build a Stable and Lasting Peace,' $3-4$.

135 Government of Colombia and FARC, 199.

136 Government of Colombia and FARC, 15 .

137 Government of Colombia and FARC, 11. 
transition from armed conflict to peace, in which international law is attracting increasing attention, evident in the recent work by the $\mathrm{ILC}^{138}$ and legal scholarship. ${ }^{139}$ Then, this experice offers new elements from practice that contribute to the legal grounding of a principle of environmental protection in transition for future processes around the world.

Both jus ad bellum and jus in bello have relatively clear addressees. In jus ad bellum, the UN Charter defined the conditions and actors to allow the legal use of force. In jus in bello, IHL is addressed to the fighting parties in armed conflict. However, the transition from armed conflict to peace is a complex process involving a variety of actors at all levels, both domestically and internationally.

For Patterson, defining who is an actor of jus post bellum means identifying "who has the obligation to do what?"140 In this sense, jus post bellum would involve any actor with obligations in the transition from armed conflict to sustainable peace. Thus, it would go beyond merely the parties in conflict or in negotiation. As May argues, the addressees of jus post bellum are not only the parties in the peace negotiations and the political leaders, but also all the citizens. $^{141}$

Under the understanding of jus post bellum proposed in this chapter, its actors cannot be limited to the direct addressees of legal obligations, but involve all actors invoking, interpreting, or applying legal norms, discourses, and comparative practices with a view to achieve a sustainable transition from armed conflict to peace. This standpoint is clear in the Colombian case. In addition to the parties' commitment to international law during peace negotiations, a broad range of external and domestic actors has played a role in the normative internationalization of transition in the country. This section presents these actors and their contribution to incorporating principles of jus

138 Jacobsson, 'Third Report on the Protection of the Environment in Relation to Armed Conflicts.' And, Report of the International Law Commission to the General Assembly, Seventy-first session, 2 May-10 June and 4 July-12 August 2016, UN Doc. A/71/10, http:// legal.un.org/docs/?path=../ilc/reports/2016/english/a_71_10.pdf\&lang=EFSRAC, 309.

139 Stahn, Iverson, and Easterday, Environmental Protection and Transitions from Conflict to Peace: Clarifying Norms, Principles, and Practices.

140 Patterson, 'Conclusion. Toward a Twenty-First Century Jus Post Bellum,' 222.

141 Larry May, 'Jus Post Bellum, Proportionality and the Fog of War,' European Journal of International Law 24, no. 1 (2013): 318-19. 
post bellum in the Colombian transition, offering insights for understanding the variety of actors that can play a role in jus post bellum in general.

\subsection{The Parties in Negotiation}

Within the context of a peace process, the parties in negotiation are the main actors of jus post bellum. In the case of a NIAC, the state has the primary duty to observe its international obligations applicable to matters in negotiation. However, non-state actors could also have an interest in following those obligations, pursuing international acceptability and legal grounding for the resulting agreement.

Unlike most peace processes, where negotiators are rarely preoccupied with international law and want to be free of legal restraints, ${ }^{142}$ in Colombia the parties in negotiation deliberately seized international law as a parameter for their talks and for their agreement. Even though the negotiation agenda did not include any specific reference to international law, the development of negotiations, the regular joint communiqués, and the Final Agreement consistently involved several international legal references. In this way, the parties showed their acknowledgment of international law, accepting the existence of unavoidable international legal obligations as well as the opportunity to frame the negotiation and the agreement under such a regime.

Indeed, both the Colombian government and the FARC wanted an agreement that would be internationally accepted. The government was responsible for ensuring the conformity of the peace deal with the State's international legal obligations. The FARC wanted to obtain legal certainty beyond the domestic order. Those elements not only eased their acceptance of external guidelines but also their search for reconciling international legal standards with the political needs of peace. Thus, in the Agreement the parties explicitly affirmed their determination to reach peace within the parameters of international law, ${ }^{143}$ which is then reflected in many aspects of the document, as analyzed in the Chapter 2.

\subsection{External Guarantors}

As noted by Bell, external backing and mediation in peace negotiations and agreements is the rule rather than the exception. ${ }^{144}$ Such a rule has been present in the 2012-2016 peace negotiations in Colombia. However, rather

\footnotetext{
142 Kastner, Legal Normativity in the Resolution of Internal Armed Conflict, 68-69.

143 Government of Colombia and FARC, 'Final Agreement to End the Armed Conflict and Build a Stable and Lasting Peace,' 144.

144 Bell, On the Law of Peace, 66.
} 
than mediation, the parties assigned to external actors the role of guarantors (Cuba and Norway) and partner states (Chile and Venezuela). ${ }^{145} \mathrm{~A}$ similar role was assigned to the UN, which participated in the talks through a SecretaryGeneral's Special Representative and received a monitoring mandate for the implementation phase. ${ }^{146}$

In normative terms, these external actors have played an essential role in bringing international law standards to the negotiation process and to the Agreement. Regarding this topic, Kastner highlights that external actors "not only assist the negotiation parties in generating their proper normative framework but are also norm promoter and norm creators who may introduce predominantly external norms into the negotiations." 147 This was the case in Colombia.

During the negotiations, Norway, as a guarantor, offered and sponsored a group of experts in international law and transitional justice to counsel the parties during the process. The group was chaired by Morten Bergsmo, a prestigious professor of international law and former advisor to the ICC and the ICTY. The group was tasked with advising on the legal limits that the peace agreement could have vis-à-vis Colombia's international legal obligations. ${ }^{148}$

Because of the confidentiality of the negotiations, it is difficult to know the terms in which that external legal advice was presented and assumed by the parties around the table. However, considering the international legal consistency of the Final Agreement, one could deduce that the role played by those external actors was vital for such an outcome. In addition to the technical legal advice provided by the experts in the negotiation, the external guarantors likely claimed for the observance of international standards. It is difficult to imagine that the same result could have been achieved without an independent party advising on the legal limits of the agreement. If those limits had been brought to the table only by the government, the guerrilla would have shown more resistance to accept them.

Finally, regarding the role of the UN Representative for the negotiations, his influence could be measured in terms of the inclusion of relevant $\mathrm{UN}$ guidelines in the Final Agreement. In particular, the 2004 Secretary-General Report

145 Government of Colombia and FARC, 'Final Agreement to End the Armed Conflict and Build a Stable and Lasting Peace,' 1 .

146 Government of Colombia and FARC, 214-16.

147 Kastner, Legal Normativity in the Resolution of Internal Armed Conflict, 129.

148 Hugo García and Juan David Laverde. Los arquitectos del acuerdo. El Espectador, 26 September 2015, https://www.elespectador.com/noticias/politica/los-arquitectos-del -acuerdo-articulo-588936 (accessed on 1 April 2018). 
on Transitional Justice ${ }^{149}$ recommended a series of measures to be incorporated in peace agreements, especially those regarding victims' rights, the prohibition on amnesties, and the safeguard of the rule of law..$^{150}$ Something similar could be said regarding UNSC Resolution 1325 and the participation and inclusion of women in the negotiation process and the Agreement. It is because of these elements that one can conclude that the UN considered the Agreement to have satisfied international and UN standards, and that the Security Council not only welcomed the deal but also assumed its monitoring and verification. ${ }^{151}$

\subsection{The Colombian Constitutional Court}

Colombia has a very influential Constitutional Court, which has the mandate to control the constitutionality of constitutional reforms and of any law. To do so, in addition to the Constitution, the Court must use IHRL and IHL as a parameter of constitutional control. It is because according to Article 93 of the Constitution, international human rights treaties duly ratified by Colombia are prevalent in the domestic order. This provision has been interpreted by the Court to mean that these international norms integrate a constitutional block that has the same legal status as the Constitution itself. ${ }^{152}$

As such, all the transitional norms adopted in Colombia are under the control of the Constitutional Court, both under the Constitution and under IHRL and IHL. For this reason, the Court has played an essential role in bringing international law to the discussion around the transition to peace in the country. This can be observed in at least three instances.

One instance is the constitutional exam of the 2005 Justice and Peace Law created for the demobilization of paramilitary groups. In its main decision regarding this Law, the Court used several international instruments to assess

149 UN Secretary-General, 'Report of the Secretary-General on the Rule of Law and Transitional Justice in Conflict and Post-Conflict Societies,' para. 64.

150 In addition to the presence of a UN Representative, other UN officials constantly sent messages to the table of negotiations. Among them, the OHCHR's representative in Colombia played an active role regarding the respect for international standards related to human rights abuses occurred during the conflict but affirming the UN support to the negotiations. At this point, he noted that: "It is quite clear in the international legal framework that an amnesty or a pardon cannot be included but it's not clear how far you must go with criminal law," "U.N. urges Colombia not to concede to FARC," United Press International (13 September 2012), available at: https://www.upi.com/Top_News/ Special/2012/og/13/UN-urges-Colombia-not-to-concede-to-FARC/UPI-47681347565546/ (accessed on 2 August 2018).

151 UN Security Council, Resolution 2261 (2016); UN Security Council, Resolution 2307 (2016); UN Security Council, Resolution 2366 (2017).

152 Corte Constitucional de Colombia, Sentencia C-574 de 1992. 
its constitutionality regarding reparation and justice. In an extensive reference to international law, the Court invoked the ICCPR, the American Convention on Human Rights, the International Convention on Enforced Disappearance, the Geneva Conventions and their Protocol Additional II, the Genocide Convention, the ICC Statute, ${ }^{153}$ and several sentences of the Inter-American Court of Human Rights. ${ }^{154}$ The Court used all these references to frame the State's international legal obligation to ensure victims' rights to truth, justice, and reparation, especially regarding the prohibition on amnesties for grave violations of IHRL and IHL. Based on this legal framework, the Court modified some aspects of the Law, increasing the perpetrators' measures of accountability and responsibility with respect to reparations for victims. ${ }^{155}$

Another instance is the constitutional exam of the 2012 Legal Framework for Peace. ${ }^{156}$ This instrument was adopted, before the peace negotiations with the FARC began, with the purpose of providing a legal basis for the future transitional mechanisms that could be required. In its judgement, the Court extensively examined relevant international treaties, international human rights jurisprudence, and international practice on transitional justice. Using those references, the Court defined the international standards that the Legal Framework for Peace should have observed in terms of reparation to victims ${ }^{157}$ and justice for international crimes. ${ }^{158}$

In the third instance, the Court has been a fundamental actor for the normative development of the 2016 Peace Agreement, and its previous decisions had clear influence during the negotiations. In the same way that the threat of a possible intervention by the ICC influenced matters of criminal justice, the parties' knowledge that any norm developing the Agreement would be submitted to the Court's control caused them to carefully follow its previous jurisprudence on transitional justice. In this sense, the Court indirectly influenced the normative internationalization of the Peace Agreement because of the international legal background of its previous jurisprudence on this matter. This was especially the case for the incorporation of international standards on the right to reparation and the prohibition of amnesties for international crimes.

\footnotetext{
153 Corte Constitucional de Colombia, Sentencia C-370/o6 paragraph 4.3.

154 Corte Constitucional de Colombia, paragraph 4.4.

155 For the Court, the broad purpose of that law "was valid, but added that the Law had to be more stringent in order to comply with constitutional and international legal standards." Kalmanovitz, 'Introduction: Law and Politics in the Colombian Negotiations with Paramilitary Groups,' 7 .

${ }_{15} 6$ Corte Constitucional de Colombia, Sentencia C-579/13.

157 Corte Constitucional de Colombia, paragraph 7.2.

158 Corte Constitucional de Colombia, paragraph 8.1.3.
} 


\subsection{The Prosecutor of the International Criminal Court}

Under current international law, the ICC should be considered a part of any transitional justice process, and the parties in conflicts should take seriously the possibility of an ICC intervention in cases where negotiation terms do not meet the Rome Statute's standards. ${ }^{159}$ This question has been present in Colombia since the very beginning of the ICC's mandate. Indeed, when Colombia deposited its instrument of ratification to the Rome Statute in 2002, a declaration was made in the sense of deferring the competence of the ICC for war crimes for seven years. ${ }^{160}$ The declaration was made with the purpose of facilitating peace negotiations with armed groups in the country during the meantime.

In 2003, Colombia initiated a negotiation for the demobilization of paramilitary groups. A year later the ICC Prosecutor put the country under preliminary examination, ${ }^{161}$ which she has kept open until now. During these years, the Rome Statute and the examination by the ICc Prosecutor have been invoked by different actors as a reminder of the international legal obligation to ensure justice for crimes under the Court's jurisdiction. The consideration of the ICC was reflected in the discussion of the Justice and Peace Law for that demobilization. When the Constitutional Court examined the constitutionality of this law, most interventions invoked the ICC Statute to claim greater accountability, and the Court used such an instrument as a parameter to support its decision to modify some aspects of the Law. ${ }^{162}$

In 2012, Colombia adopted a constitutional reform developing a Legal Framework for Peace that included the possibility of granting alternative penalties or the suspension of sentences for members of armed groups. ${ }^{163}$ This norm was examined by the Constitutional Court in 2013, and the ICC Prosecutor intervened in the process through two letters expressing her concern regarding these benefits. In the first letter she argued that since the suspension of a prison sentence means that the accused does not spend time imprisoned, it would be manifestly inadequate in the case of those most responsible for committing international crimes. ${ }^{164}$ In a second letter, sent a few weeks later, the

159 Ambos, 'The Legal Framework of Transitional Justice,' 67-68.

160 The Office of the Prosecutor, 'Report on Preliminary Examination Activities 2016,' para. 233 .

161 The Office of the Prosecutor, para. 231.

162 Corte Constitucional de Colombia, Sentencia C-37o/o6 paragraph 4.3.8.

163 Congreso de la República de Colombia, Acto Legislativo or de 2012.

164 Letter of 26 July 2013, sent by the Prosecutor of the ICC to the Colombian Constitutional Court. Corte Constitucional de Colombia, Sentencia C-579/13 paragraph 3.16.1. 
Prosecutor emphasized that the ICC maintains its competence over individuals who committed crimes enshrined by the Rome Statute, even if they have received judicial benefits under domestic law. ${ }^{165}$

In 2015, in a conference on transitional justice and the ICC in Colombia, the ICC Deputy Prosecutor explained the Prosecutor's position in a more moderate way. In his opinion, criminal sentences can adopt different forms in transitional contexts: absolute suspension of sentences is not possible, but prison time is not an indispensable punishment. ${ }^{166}$ This statement supported the idea that in contexts of transition, alternative measures offering effective restrictions of liberty were enough to meet the ICC's standards on punishment.

All of these elements have played a significant role in the transition in Colombia. The mechanism of criminal responsibility and prison sentences applied to paramilitary groups under the 2005 Justice and Peace Law were possible owing to the potential threat of an ICC intervention. ${ }^{167}$ This was also the case in the 2016 Peace Agreement with the FARC. Indeed, even though the guerrilla did not accept the same prison sentences as those applied to paramilitaries, the negotiators understood that the ICC Prosecutor would not accept simple restorative sanctions for individuals responsible of the most serious crimes. In this sense, the Final Agreement incorporated the Deputy Prosecutor's perspective, introducing effective restrictions of liberty as a part of the restorative sanctions agreed by the parties.

As such, the ICc Prosecutor welcomed the terms of the Peace Agreement. ${ }^{168}$ In a subsequent visit to the country, the Prosecutor declared herself "impressed by the commitment, invaluable experience and high standards of Colombian courts," and reaffirmed the disposition of her office to keep "as a good faith partner of the Colombian government and the Colombian people in this journey towards sustainable peace."169

165 Letter of 7 August 2013, sent by the Prosecutor of the ICC to the Colombian Constitutional Court. Corte Constitucional de Colombia, paragraph 3.16.2.

166 James Stewart, Deputy ICc Prosecutor, 'Transitional Justice in Colombia and the Role of the International Criminal Court.'

167 Kastner, Legal Normativity in the Resolution of Internal Armed Conflict, 168. In the same line, see Jose Arvelo, 'International Law and Conflict Resolution in Colombia: Balancing Peace and Justice in the Paramilitary Demobilization Process,' Georgetown Journal of International Law 37, no. 2 (2006): 447.

168 Office of the ICC Prosecutor, 'Statement of ICC Prosecutor, Fatou Bensouda, on the Conclusion of the Peace Negotiations between the Government of Colombia and the Revolutionary Armed Forces of Colombia.'

169 Statement of the Prosecutor of the International Criminal Court, Fatou Bensouda, on the conclusion of her visit to Colombia (10-13 September 2017), https://www.icc-cpi.int// Pages/item.aspx?name=170913-otp-stat-colombia (accessed on 17 April 2018). 
These statements reflect the Prosecutor's satisfaction with the way in which the parties in negotiation accepted and applied her recommendations, showing the influence of the ICC in the Colombian transitional justice mechanisms since 2005. This Prosecutor's support plays a very positive role in giving legitimacy and legal certainty to the Agreement. On this point, one can conclude that if criminal accountability is effectively ensured in the agreed terms, a future ICC intervention would be unlikely in this case. ${ }^{170}$

\subsection{The Inter-American System of Human Rights}

Both the Inter-American Commission and the Inter-American Court of Human Rights have made significant contributions to the development of I H RL regarding truth, justice, and reparation, and they have influenced its incorporation into domestic law and practice. ${ }^{171}$ As discussed in the previous chapter regarding the prohibition on amnesties for serious violations of human rights, the Commission and the Court developed a consistent jurisprudence on the State's obligation to investigate and prosecute those crimes, as well as to provide reparation for victims of dictatorial regimes and armed conflicts in the continent. The Court has even rejected the validity of domestic laws involving impunity in those cases. ${ }^{172}$

The Inter-American System of Human Rights' jurisprudence has been invoked by several organizations and by the Constitutional Court during the constitutional control for the norms on transitional justice in Colombia. NGO s and academia's interventions before the Constitutional Court during the exam of the Justice and Peace Law and the Legal Framework for Peace invoked the Inter-American jurisprudence on human rights as a reference for the State's international obligations. And, indeed, the Constitutional Court extensively referred to several Inter-American Court sentences as parameters of constitutional control. ${ }^{173}$ Such decisions were mainly related to positive obligations to prevent, investigate, and sanction human rights violations; ${ }^{174}$ the

170 Sanchez, 'Could the Colombian Peace Accord Trigger an ICC Investigation on Colombia?', 176.

171 Juan Méndez and Catherine Cone, 'Human Rights Make a Difference: Lessons from Latin America,' in The Oxford Handbook of International Human Rights Law, ed. Dinah Shelton (Oxford: Oxford University Press, 2013), 979.

172 Inter-American Court of Human Rights, Case of the Massacres of El Mozote and nearby places v. El Salvador, Judgement of 25 October 2012.

173 Corte Constitucional de Colombia, Sentencia C-37o/o6; Corte Constitucional de Colombia, Sentencia C-579/13.

174 Caso Godínez Cruz vs. Honduras; Caso Hermanos Gómez Paquiyauri vs. Perú. 
inadmissibility of amnesties for those violations ${ }^{175}$ and the invalidity of laws granting such amnesties; ${ }^{176}$ the victim's right to an effective remedy, including reparation, ${ }^{177}$ and the right to truth. ${ }^{178}$

Considering these elements, the Constitutional Court made significant adjustments to the 2005 Justice and Peace Law, which were expressly welcomed by the Inter-American Commission. The Commission issued an official statement analyzing the Law and the Constitutional Court's judgment under the Inter-American standards on human rights. For the Commission, the Court's decision substantially improved the Law's balance between the need to grant judicial benefits in exchange for contributions to peace with the international standards on truth, justice, and reparation. On this matter, the Commission affirmed that the Court's decision constituted an essential tool to interpret and apply the Colombian transitional legal framework according to the State's international human rights obligations. ${ }^{179}$ Therefore, the precedents of the Inter-American System became crucial considerations for the parties during the 2012-2016 peace negotiations.

\subsection{Victims and Civil Society Organizations}

NGOs working on human rights and other related sectors are fundamental actors in the process of transition to peace. As noted by Davis, "their experience in litigation and political incidence have contributed for example to the development of a strong jurisprudence on victims' rights in Latin America."180 At the same time, IHRL has played a fundamental role in legitimizing different civil society's claims and discourses. NGO s have used international law "in advocacy, campaigning, fact-finding reports, complaints to international bodies, briefs to courts, and to develop the scope and efficacy of the international human rights institutional framework."181

\footnotetext{
175 Inter-American Court of Human Rights, Case of the Massacres of El Mozote and nearby places v. El Salvador, Judgement of 25 October 2012. Inter-American Court of Human Rights, Case of 'Mapiripán Massacre' v. Colombia, Judgment of ${ }_{15}$ September 2005.

${ }_{176}$ Inter-American Court of Human Rights, Case of the Massacres of El Mozote and nearby places v. El Salvador, Judgement of 25 October 2012.

177 Caso Myrna Mack Chang vs Guatemala; Caso comunidad Moiwana vs. Suriname.

178 Caso Bámaca Velásquez vs Guatemala.

179 Inter-American Commission on Human Rights, Pronunciamiento de la Comisión Interamericana de Derechos Humanos sobre la aplicación y el alcance de la Ley de justicia y paz en la República de Colombia, 2006, http://www.cidh.org/countryrep/ Colombia20o6sp/pronunciamiento.8.1.o6esp.htm (accessed on 15 April 2018).

180 Jeffrey Davis, Seeking Human Rights Justice in Latin America: Truth, Extra-Territorial Courts, and the Process of Justice (Cambridge: Cambridge University Press, 2014), 224.

181 Andrew Clapham, 'The Use of International Human Rights Law by Civil Society Organisations,' in Routledge Handbook of International Human Rights Law, ed. Sheeran Rodley, Sir Nigel Scott (London: Routledge, 2013), 153.
} 
As such, civil society organizations have also contributed to the international legal background of the transition to peace in Colombia. Besides their general advocacy in media and political scenarios, they have held a concrete role in the discussion of transitional justice norms before the Constitutional Court. During the examination of the 2005 Justice and Peace Law and the 2012 Legal Framework for Peace, the Court considered the interventions and briefs submitted by several local NGO s and think tanks, as well as international ones like the International Commission of Jurists, ${ }^{182}$ the International Center for Transitional Justice, Human Rights Watch, and Amnesty International. ${ }^{183}$ In all of their interventions, these organizations invoked international law asking the Court to ensure international standards on justice and reparations to victims.

Those legal discourses in media and before the Court have impacted the way in which the legal mechanisms were designed and adapted. On the Justice and Peace Law, Evans highlights that "the consistent pressure by international and regional human rights mechanisms, as well as by national civil society organisations, has played a major role in highlighting concerns relating to reparations." ${ }^{184}$ Similarly, one could consider the influence of human rights advocacy on matters such as victims' participation during the peace negotiations and the broad gender dimension of the 2016 Peace Agreement. These issues were not present in the initial agenda of negotiations, but they were introduced and accepted by the parties during the process owing to the pressure by victims, NGOs, and other related actors.

On this line, the role of victims during the peace negotiations in Colombia expressed their potential to bring legal standards and discourses to the discussion on matters involving their rights. Victims played a fundamental role both through their public advocacy and through their direct participation in the table of negotiations for having a Peace Agreement observing international legal standards on victim's rights.

\subsection{Insights on the Type and Role of Actors of Jus Post Bellum}

From the variety of actors and functions played by them in the Colombian transition, one can find relevant insights for understanding the type and role of actors of jus post bellum in general. As suggested in this section, an actor of jus post bellum is everyone playing a role in defining, bringing, interpreting,

182 Corte Constitucional de Colombia, Sentencia C-370/o6 paragraph 3.

183 Corte Constitucional de Colombia, Sentencia C-579/13 paragraphs 3, 4.

184 Evans, The Right to Reparation in International Law for Victims of Armed Conflict, 221. 
and applying relevant international law as a frame for transitioning from armed conflict to sustainable peace.

If jus post bellum is a normative framework that guides the contextualized interpretation and application of international law for the transition to peace, the way in which this framework operates and the principles that define its substance, as seen in this chapter, mean that the range of actors that can play a role in this process is wide and open. This section offered a varied list of domestic and international actors in Colombia, without being exhaustive. The common element among them was their contribution to define a normative framework in which the formulas for transition were built on different matters, having as a goal addressing the root causes of armed conflict and observing international standards on human rights, democracy, and the rule of law. Thus, according to the conceptual and empirical analysis presented here, playing a role on such a task can be considered as the distinctive element to identify the actors of jus post bellum in any given context.

As such, the Colombian experience shows at least four kind of relevant actors that could be generally seen as the basic categories to classify actors of jus post bellum in other contexts.

First, direct parts in negotiation are the main actors of jus post bellum. Regardless of the efforts made by other institutions or actors, the parties directly involved in finding a solution to their armed conflict are at the center of decisions, and their understanding and commitment to the normative legal framework guiding transition is a condition to make possible a successful transit from armed conflict to peace under the parameters of jus post bellum.

Second, external actors such as mediators, guarantors, the UN, and other relevant international institutions are essential to facilitate the incorporation of international legal norms, discourses, and practices into the specific transitional process. As seen in Colombia, the guarantor countries, the UN representative, the ICC Prosecutor, and even the Inter-American human rights institutions played a role at bringing to the table and to the institutional and public discussions international standards as derived from the State's international obligations and from the comparative practice on the matter. This external contribution was essential to make the parties aware on the legal limits and possibilities shaping their negotiation. The specific actors relevant for other contexts will depend on different conditions but that support by international actors is essential to facilitate transition from a NIAC to peace under the vision of jus post bellum.

Third, domestic institutions are also key actors for a successful observance of jus post bellum in transitions from NIACs. This section only referred to the Constitutional Court in Colombia, but other actors such as the parliament and 
other courts, for example, have played a role in the normative internationalization of the Colombian transition. In other contexts, those actors will depend on the institutional design or the institutional situation of the country, but experience from this case study shows how relevant is to have domestic institutions ensuring compliance with international legal standards both for the design and for the implementation of transitional mechanisms.

Fourth, experience in the case study shows how the active involvement of victims and other civil society actors is a fundamental component of jus post bellum. As discussed on the principle of inclusiveness, the normative dimension of inclusion is getting increased attention in international law and it plays a vital role for making peace legitimate and sustainable. Then, the participation of victims and other civil society actors not only ensures their involvement in the peacebuilding process but those actors can also bring to the discussion international standards to be observed in the protection of their rights and those of society.

The Functions Played by International Law in the Colombian Transition: Possible Functions of Jus Post Bellum?

Considering the significant role played by international law in the Colombian transition, this case offers important insights on the possible functions of $j u s$ post bellum as a framework involving the application of international law to transitions from armed conflict to peace. Based on that view, this section presents some functions played by international law in the transition to peace in Colombia, and how they could be more generally understood as functions of jus post bellum.

\subsection{Increasing International Legitimacy of Transitional Mechanisms}

In a global world, the international acceptance of peace agreements and other transitional mechanisms can be a condition for their successful and sustainable implementation. Such acceptance is largely dependent on the conformity of those mechanisms with international law.

In the Colombian case, the adherence of the peace negotiations and the Peace Agreement to international law is at the basis of their broad international support. It is evident, for instance, in the extensive involvement of the UNSC in monitoring implementation, and in the welcoming messages by the ICC Prosecutor regarding transitional justice mechanisms. It creates a favorable environment for donors and external agencies supporting the implementation of the agreement and can also have effects on the domestic 
level, increasing the credibility of the process and encouraging all actors around its compliance.

\subsection{Offering Legal Certainty to the Peace Agreement}

One of the main reasons why the parties based the Colombian Peace Agreement on international law was to lend it legal certainty beyond domestic law. This can be identified in at least two instances. One is the legal shielding of the Agreement as an international legal accord, which was a purpose shared not only by both parties but also by other actors of civil society and external guarantors facing the threat of future modifications to the Agreement by its opponents. This function is very relevant in the case of NIACs, as usually there are sectors opposing the peace agreement that could have the power to modify what was agreed. Here, the shielding function attributed by the negotiators to international law in the Peace Agreement expresses a creative use of international legal norms and mechanisms, and it constitutes a significant contribution to the debate on the functions that jus post bellum as normative framework can play.

Second, the international acceptance of the Peace Agreement, specially by the Office of the ICC Prosecutor and the UnSC, creates an expectation that the deal will be respected by international legal institutions. For instance, in the field of criminal responsibility for international crimes, one could reasonably expect that individuals responsible for such crimes who are duly submitted to the transitional justice system created by the Agreement would not later be prosecuted by those facts in Colombia or abroad. It is an important expression of legal certainty, in view of the risk of any re-opening of criminal processes if the ICL's exigences are not met, and the fact that the ICC keeps competence regardless of the domestic benefits granted by the State. Here, the guidance of international law for the definition of the system of criminal justice was essential to reaching a formula designed to satisfy the ICC's complementarity test. Similarly, it would be expected that the adherence to international standards on truth, justice, and reparation could shield the Agreement from situations like the annulation of domestic laws because of their incompatibility with IHRL standards, as it has occurred in Latin America in some cases following recommendations of the Inter-American System of Human Rights. ${ }^{185}$

185 Some examples include Argentina (La Nacion, Diputados derogó la obediencia debida, 25 March 1998, https://www.lanacion.com.ar/politica/diputados-derogo-la-obedienciadebida-nid9150o, accessed on 10 March 2017); Chile (Publico, Chile deroga el decreto ley de amnistía aprobado por la dictadura, 12 September 2014, https://www.publico.es/ internacional/chile-deroga-decreto-ley-amnistia.html, accessed on 10 March 2017); El Salvador (El Nuevo Herald, Supremo salvadoreño deroga Ley de Amnistía, 10 July 2016, 


\subsection{Delimitating a Bargaining Zone for Negotiations}

In peace negotiations, international law helps to delimit the parties' expectations within a framework external to them. It is particularly important considering that in NIAC s non-state armed groups generally reject the state's institutions and norms. Thus, framing the negotiations under international law places state and non-state actors in a certain position of parity regarding their obligations and expectations. In such cases, it would be easier for nonstate actors to accept conditions that the state cannot ease on in negotiation because it is constrained by its international obligations. ${ }^{186}$

In the Colombian case, this is especially visible in the field of justice. On the one hand, if the parties wanted the Agreement to be protected and governed by international law, they had to accept that the Additional Protocol II's provision on amnesties needed to be balanced with the State's duty to prosecute international crimes. On the other hand, the fact that the State's margin of decision is limited by its international obligations implies that even if the government wanted to accept lower standards, it cannot ensure that they would be respected domestically and internationally. The ICC's competence, the preceding reopening of domestic judicial processes against beneficiaries of amnesties in Latin America, and the possibility of prosecutions by foreign courts under the principle of universal jurisdiction caused the guerrilla to accept that criminal responsibility was a necessary condition under international law rather than a mere exigence of the government.

\subsection{Creating Confidence among the Parties}

In a NIAC, at least a non-state actor is fighting the institutional system, including its legal order. Such an actor is likely to distrust a negotiation conducted exclusively under the domestic normative framework it is fighting against. In the Colombian case, framing the negotiation under an international legal angle increased trust among the parties, as they felt backed by norms, actors, and institutions beyond mere domestic law.

https://www.elnuevoherald.com/noticias/mundo/america-latina/article89949847.html (accessed on 10 March 2017).

186 On this point, Saffon and Uprimny point out that "legal standards on victims' rights would work not as obstacles to peace, but rather as virtuous restrictions that channel peace negotiations, by restricting the available political options for framing them, and by bringing conflicting interests and expectations of different actors closer-even to the point of generating consensual spaces among them." Saffon and Uprimny, 'Uses and Abuses of Transitional Justice in Colombia,' 388 . 
On this matter, Kastner argues that 'international law may offer a 'shade' under which peace negotiations can take place in a more legitimate, and as a result more effective way, by pulling the actors involved towards this shade and spurring compliance."187 This confidence can be enhanced by the fact that an international framework offers a certain impartial language in which parties can find common and reconcilable points, at the time that international law recognizes in neutral terms the status of the non-state actors in negotiation. ${ }^{188}$

\subsection{Empowering Traditional Marginalized Actors}

International law empowered different groups in Colombia in their demands for participation and inclusion in the design of transitional mechanisms and in the peace process. This function of international law is described by Kastner as a legal empowerment allowing vulnerable groups not only to be aware of their rights and the use of law to protect them but also, in the context of transitional processes, "to contribute to forming the legal-normative framework of peace negotiations." 189

International law gave force to victims' discourses and demands during the peace process and in the Agreement in Colombia. Since 2005, international law has backed victims' claims to increase the exigences of truth, justice, and reparation in the initial Alternative Penalties Law, which caused the government and the Congress to move towards a more comprehensive Justice and Peace Law. ${ }^{190}$ Victims' demands had true impact because they were grounded on international law. In this way, their discourse transcended a political dimension and attained a normative power. ${ }^{191}$ On this point, the 2016 Peace Agreement declares that it seeks to respond to the expectations of the victims and society in general, as well as to the State's national and international obligations. ${ }^{192}$

When people can invoke international legal obligations to support their demands in a context of transition, they receive greater visibility and international support, a result that consequentially improves their chances of being heard and included. This occurs because of international pressure to negotiate

187 Kastner, Legal Normativity in the Resolution of Internal Armed Conflict, 16-17.

188 Jorge Esquirol, 'Can International Law Help? An Analysis of the Colombian Peace Process,' Connecticut Journal of International Law 16, no. 1 (2000): 39.

189 Kastner, Legal Normativity in the Resolution of Internal Armed Conflict, 146.

190 Saffon and Uprimny, 'Uses and Abuses of Transitional Justice in Colombia,' 392-93.

191 Saffon and Uprimny, 373.

192 Government of Colombia and Farc, 'Final Agreement to End the Armed Conflict and Build a Stable and Lasting Peace,' 129. 
according to international law and the negotiators' growing interest to have an agreement internationally accepted. This is particularly visible with respect to the increased attention paid to women in peace negotiations around the world after UNSC Resolution $1325 .{ }^{193}$

Additionally, the Colombian experience shows that the international legal development on women's participation and inclusion in peace processes can serve as an example for approaching other identity groups, which are equally essential to achieving peace. ${ }^{194}$ This is especially the case for LGBTI people, whose rights are receiving increasing legal attention at the international level. ${ }^{195}$ Similarly, for ethnic communities, their international legal protection through ILO Convention 169 and UN declarations can be enhanced with the communities' specific participation and inclusion in peace processes, following the example of the framework created for women by UNSC Resolution 1325 .

\subsection{Promoting Comprehensiveness in the Guarantee of Rights}

Following international standards, the Colombian Agreement integrates justice, truth, and reparation as an indivisible whole. The Agreement states that these three components are all aimed at ensuring victims' rights with no one component prevailing over the others. ${ }^{196}$ This system looks at accomplishing the State's positive obligations under IHRL, a regime under which states have the responsibility not only to investigate and punish violations of human rights but also to prevent them, search for the truth, repair the victims, guarantee the non-repetition of violence, and maintain public order. ${ }^{197}$ This combined

193 Helen Durham, 'From Paper to Practice: The Role of Treaty Ratification Post-Conflict,' in The Role of International Law in Rebuilding Societes After Conflict, ed. Brett Bowden, Hilary Charlesworth, and Jeremy Farrall (Cambridge: Cambridge University Press, 2009), 194.

194 On this point, Anderlini notes that "where political or identity issues are at the root of conflict, women can use their gendered identities and social experiences to bridge these chasms and set an example for other in their own identity groups." Anderlini, Women Building Peace: What They Do, What It Matters, 126.

195 The visibility of LGBT rights at international law level started in 2011 with UN Human Rights Council Resolution 17/19 (2011). In 2016, the Council created a mandate for an Independent Expert on protection against violence and discrimination based on sexual orientation and gender identity, through Resolution $32 / 2$ (2016), UN. Doc. A/HRC/RES/ $32 / 2$.

196 Government of Colombia and FARC, 'Final Agreement to End the Armed Conflict and Build a Stable and Lasting Peace,' 130.

197 Inter-American Court of Human Rights, Case of the Massacres of El Mozote and nearby places v. El Salvador, Judgement of 25 October 2012 Concurrent Opinion Judge Diego García-Sayán et. al., para. 23. See also Acosta-Lopez, 'The Inter-American Human Rights System and the Colombian Peace: Redefining the Fight Against Impunity,' 179. 
approach is the best way to comprehensively satisfy victims' rights in contexts of transition, which is unlikely to be achieved through only criminal retribution for past violations. ${ }^{198}$ On this point, it is important to remember that such a comprehensive approach was not envisaged in the agenda of negotiations, in which the guerilla was reluctant to accept any form of justice but agreed to include a component on victims' rights. It was here that, owing to the comprehensive approach to victims' rights in international law, all components on truth, justice, and reparation were finally developed during the peace process.

\subsection{Encouraging the Transformative Role of Transition}

As discussed above, jus post bellum looks for a positive transformation of the status quo ante rather than simply its restoration, especially in contexts of transition from NIACs to peace. In the Colombian case, the ways in which international law has shaped transition strengthened the transformative role of transitional mechanisms to build peace. This effect can be seen in at least three components.

First, the establishment of a reparation system, even during the ongoing armed conflict, shows that reparation can also play a transformative role capable of creating conditions for peace. In addition to the five measures of reparation defined by international law, the 2011 Law on Victims established a system of institutions and mechanisms to empower victims and ensure their participation at different levels. It paved the way for the significant victims' support to the 2012-2016 peace negotiations with the guerrilla. Reparation thus assumed a dual role, both correcting violations of human rights and fostering transformation and reconciliation in a broad sense, ${ }^{199}$ which definitively helped to create conditions for peace.

Second, by empowering groups to participate and be included in peace talks and agreements, international law can contribute to the openness of societies in transition. If the participation and inclusion of different groups is seen as a legal standard rather than a mere political choice, transitions will be better used as an opportunity to address structural discriminatory dynamics in society. ${ }^{200}$ On this point, Kastner claims that "an agreement may not only

198 Chetail, 'Introduction,' 23.

199 On this idea, see: Marco Sassòli, 'Reparation,' in Post-Conflict Peacebuilding: A Lexicon, ed. Vincent Chetail (Oxford: Oxford University Press, 2009), 283. Ruth Rubio-Marín, 'Gender and Collective Reparations in the Aftermath of Conflict and Political Repression,' in The Gender of Reparations, ed. Ruth Rubio-Marín (Cambridge: Cambridge University Press, 2009), 383 .

200 According to Maguire, transitional contexts are scenarios in which new frameworks can be established to promote the transformation of social unfair realities, and law plays a 
symbolize a concerted attempt to end an armed conflict but may also aspire to solve structural problems and generate fundamental changes in a post-conflict society."201 In the Colombian case, no previous attempt to negotiate peace has had a similar approach. And though the effects of this inclusiveness are to be seen in the coming years, the fact that different groups were heard during the negotiations and their demands included in the Agreement represents a promising opportunity for shaping a more inclusive country. ${ }^{202}$

Finally, the Colombian peace negotiations gave a central role to the discussion on the root causes of armed conflict. The objective of establishing a sustainable peace requires not only ending armed confrontation but also addressing its causes. On this point, the Peace Agreement looks at improving rural development and political participation in Colombia, ensuring all civil, political, economic, social, and cultural rights. A successful implementation of those measures would bring positive transformations in the quality of life of millions of people in the regions most affected by armed conflict.

\subsection{Insights for the General Functions of Jus Post Bellum}

This section explored the functions played by international law in the Colombian case suggesting how they could reflect possible functions of jus post bellum. The seven functions discussed here show the contributions of international law in the Colombian transition, from facilitating negotiations and increasing confidence among the parties to promoting comprehensive transformations and the participation of traditionally marginalized groups. All those functions certainly express the purposes of jus post bellum.

vital role accomplishing such a task. Therefore, participation of women and other relevant groups must be ensured when creating those frameworks. Amy Maguire, ' "Security Starts with the Law": The Role of International Law in the Protection of Women's Security PostConflict,' in The Role of International Law in Rebuilding Societes After Conflict, ed. Brett Bowden, Hilary Charlesworth, and Jeremy Farrall (Cambridge: Cambridge University Press, 2009), 223, 242-43.

201 Ibid., 68.

$2 \mathrm{O} 2$ Regarding this idea, Bell and O'Rourke note that the very fact of mentioning an issue in the agreement gives a base for interested groups to defend it during the implementation. For them, "[w]hile the terms of a peace agreement do not secure the implementation of its provision, and the omission of an issue does not mean that it cannot be addressed in practice, issues that are not specifically mentioned in the agreement can be difficult to prioritize post-agreement, and importantly, international implementation mechanisms and donor funding flow from the agreement's priorities": Bell and O'Rourke, 'Peace Agreements or Pieces of Paper? The Impact of UNSC Resolution 1325 on Peace Processes and Their Agreements,' 947. 
In that way, even if the above-mentioned functions are presented as serving specific features of the Colombian context, most of them are also relevant to other cases. However, to summarize their content towards suggesting more general functions of jus post bellum in transition from NIACs to peace, they could be gathered into three possible global functions.

First, helping to delimitate the matters to be addressed in peace negotiations or any other transitional mechanism, by looking to comprehensively address the causes and the consequences of armed conflict under international legal standards. Even though each context has its own conditions, a process conducted under the framework of jus post bellum must include matters as reconstruction and transformation, reparations for victims, and criminal accountability for crimes committed during the conflict, among others. Here, as seen in the section on principles, a framework of jus post bellum brings to the discussion the international legal norms, discourses, and practices guiding the treatment of the specific matter, delimiting the negotiation and the conclusion of the corresponding mechanisms.

Second, a framework of jus post bellum shows the actors that must be involved in transitional processes, giving legal grounds for traditionally marginalized groups to be included in order to make transition to peace legitimate, sustainable, and socially supported. This is an essential component on current peacemaking and peacebuilding, where the more people can participate and their concerns be considered the more accepted and effective can be the construction of sustainable peace.

Third, the framework of jus post bellum conveys international legal mechanisms and institutions to facilitate negotiations, the conclusion of peace agreements, and their successful implementation. A normative framework external to the parties in a NIAC helps to create confidence, and the participation of international actors as mediators or guarantors in the negotiation or in the implementation facilitates the discussion on complex matters and secures the effective monitoring and verification in the implementation phase.

This chapter developed a comprehensive analysis of jus post bellum through the lens of the Colombian case, offering empirical insights for understanding the definition, formation, principles, actors, and functions of this normative framework. The conclusions can be summarized into five components.

First, from the proliferation of theoretical definitions presented in Chapter 1, this chapter suggested a definition based on the evidence provided by the 
Colombian case. To this effect, the chapter delineated four basic features of $j u s$ post bellum: $(i)$ its content is given by principles; (ii) its object is to help establishing a sustainable peace; (iii) it holds a functional rather than a temporal approach; and, (iv) its legal nature is a matter of international law. Thus, by referring to empirical elements from the case study, this chapter defined jus post bellum as a normative framework of principles offering a space of contextualized interpretation and application of relevant international law in the transition from armed conflict to a sustainable peace. Such a framework contains normative standards and possibilities, which, rather than being restrictive, are aimed at guiding choices in transition.

Second, jus post bellum is a dynamic normative framework permanently constructed through the practice of parties involved in transition. Such parties must apply international legal norms that were not meant to regulate transitional processes, and in doing so they interpret and adapt those norms to their specific context. It implies a dual process of application and creation of law, regarding which the chapter provided concrete examples from Colombia.

Third, principles are the constituent substance of jus post bellum. They create the normative framework allowing parties to move within a set of relevant norms, discourses, and practices to balance international legal obligations with the political conditions raised by their transitional process. This chapter explored some principles present in the Colombian case, assessing their legal value and their configuration in the transition to peace in the country. Even though such a list is not exhaustive, the principles discussed offered a concrete illustration on the content of jus post bellum in practice.

Fourth, the chapter explored how different external and domestic actors played a role in bringing international legal considerations to the Colombian transition. The chapter sustained that the potential actors of jus post bellum go beyond the parties directly involved in peace negotiations, and that they concern all the potential actors that have an interest in or a responsibility for ensuring compliance with international law with a view to make transition to peace sustainable. From there, the chapter suggested some basic categories that could identify actors in other contexts.

Fifth, analyzing the functions played by international law in the Colombian transition, the chapter outlined the potential functions of jus post bellum. Here, it examined how the normative framework provided by jus post bellum can help transition in different ways, as delimiting the bargaining zone of possible agreement in peace negotiations, offering legal certainty to peace deals, increasing confidence among the parties, empowering traditionally marginalized groups, and encouraging the transformative role of transition. Here, the chapter also classified some general functions that could guide jus post bellum in other contexts. 